\title{
Economic Evaluation of Dairy Cow Stocking Density ${ }^{1}$
}

\author{
Albert De Vries, Haile Dechassa, and Henk Hogeveen²
}

\section{Introduction}

What is the optimal number of dairy cows in a pen after their transition period? In freestall barns, a pen has a fixed number of stalls in which cows can lie. In this document, the term stocking density refers to the number of dairy cows per stall. A stocking density of $100 \%$ implies that for every cow there is one stall in the pen in a freestall barn. Stocking densities greater than $100 \%$ are the rule rather than the exception on many dairy farms. High stocking densities negatively affect cow behavior and performance, but may be economically attractive because more cows in the pen help reduce fixed stall costs.

This document discusses the economically optimal stocking density for lactating dairy cows, measured as maximum profit per stall (De Vries, Dechassa, and Hogeveen 2016). It also introduces a spreadsheet that can be used to calculate the effects of various inputs on the economically optimal stocking density. Stocking densities for transition cows that are more severely affected by higher stocking densities than cows later in lactation are beyond the scope of this publication (Nordlund, Cook, and Oetzel 2006).

\section{Effects of Stocking Density on Cow Performance}

Several studies document the effects of stocking density on some aspect of cow behavior, but few studies provide quantitative relationships between stocking density and cow performance measures that directly affect profitability, such as milk production, milk quality, reproduction, or health.

\section{Behavior}

Sufficient rest is important to dairy cows. Grant (2011) reported that significant overcrowding appears to reduce feeding activity, alter resting behavior, and decrease rumination activity. In a review of eight studies, Krawczel (2012) reported that lying time seemed to start to decrease when the stocking density was greater than $120 \%$. In a designed experiment, Fregonesi, Tucker, and Weary (2007) created stocking densities of 100 to $150 \%$ and observed a reduction in lying time from 12.9 down to 11.2 hours per day, or about 20 minutes less per 0.1 greater cows/stall (e.g., from $110 \%$ to $120 \%)$.

Cook and Nordlund (2002) suggested that environments that increase the proportion of cows standing and reduce the lying time to less than 10 to 11 hours daily put cows at risk of developing lameness and other health problems.

\section{Milk Production}

Bach et al. (2008) studied the effects of stocking density and other non-dietary factors in 47 dairy herds (approximately 3,129 lactating cows) from the northeast of Spain that were offered exactly the same lactating ration. In the range of 0.83 to 1.67 cows/stall, the average loss in milk yield was 1.15 pounds/day per 0.1 cows/stall greater stocking density.

1. This document is AN346, one of a series of the Department of Animal Sciences, UF/IFAS Extension. Original publication date August 2018. Visit the EDIS website at http://edis.ifas.ufl.edu.

2. Albert De Vries, professor; Haile Dechassa, graduate student, Department of Animal Sciences; and Henk Hogeveen, professor, Wageningen University; UF/IFAS Extension, Gainesville, FL 32611. 
Grant (2011) reported a negative relationship of 3.70 pounds/day for each hour of reduced lying time. Combine that with the reduction in lying time due to overcrowding from Fregonesi, Tucker, and Weary (2007), and the result is that cows lose about 1.26 pounds per 0.1 greater cows/stall. This result is similar to that found by Bach et al. (2008).

Work by Hill and others (Krawczel 2012) showed that younger and unhealthy cows are more severely affected by overstocking when they must compete in a pen with adult and healthy cows.

\section{Reproduction}

Data on the effects of stocking density on reproductive performance are scarce. Schefers et al. (2010) reported that, based on observations in large commercial dairy farms in the Midwest, conception rate decreased by 0.1 percentage point per 0.01 greater cows/stall. In other words, in a herd with a $120 \%$ stocking density, conception rates were on average 2 percentage points lower (e.g., from $40 \%$ to $38 \%$ ) than in herds that were not overstocked.

\section{Theory of Economically Optimal Stocking Density}

Stocking density economics follows the classical law of diminishing marginal returns. This means that each additional (marginal) cow will generate an income (milk sales, calf value, cull income) at a cost that varies with the presence of the cow (feed, parlor supplies, potentially some labor). Costs that vary with the presence of the cow are variable costs. Fixed costs, or costs that are not affected by the number of cows in the pen (e.g., depreciation and most of the labor cost), are not factors in the question of optimal stocking density. Each additional cow reduces the performance of the other cows already in the pen. The economically optimal stocking density is reached when the marginal return of the pen equals the marginal cost of the pen. At this stocking density, the profit per stall is maximized. Add one more cow and the pen's marginal return becomes less than the marginal cost, and profitability per stall decreases.

\section{Calculation of the Optimal Stocking Density}

We developed a spreadsheet of a herd budget that mimics the daily movement of cows through their lactations until they are culled (De Vries, Dechassa, and Hogeveen 2016). Examples of inputs are lactation curves, feed intakes, 21-day insemination rates, probabilities of conception, and involuntary culling risk. We chose our inputs based on plausible values for US dairy herds during the last several years. The herd budget also calculates many statistics that follow from the chosen inputs, such as annual cull rate, average days open, herd milk production, revenues, costs, and profit per stall. In our analysis, stocking density affected milk production and reproduction. The effects linearly increased with stocking density greater than $100 \%$. Thus, the effects at $120 \%$ stocking density were twice as large as the effects at $110 \%$ stocking density.

Milk production was reduced by $1.1,1.5$, or 2 pounds per day per cow in the pen, per 0.1 greater cows/stall. The 1.5- and 2-pound losses are slightly greater than the 1.1 pound per day reported by Bach et al. (2008). Pregnancy per insemination was reduced by 0.1 per each increase in 0.1 cows per stall in all scenarios, as found by Schefers et al. (2010). A sensitivity analysis was conducted to reveal how the optimal stocking density depended on milk loss, milk prices, insemination rate, and fixed versus variable cost. We varied stocking density of lactating cows from $100 \%$ to $150 \%$.

\section{Results}

Based on our inputs, and with a stocking density of $100 \%$, some key results per milking stall per year were as follows: $\$ 5,307$ milk sales, $\$ 442$ cull sales, $\$ 167$ calf value, $\$ 845$ heifer enter cost, $\$ 2,973$ feed cost, and $\$ 867$ other variable costs. Fixed costs were $\$ 730$; therefore, profit was $\$ 500$. Annual milk yield was 26,001 pounds, with a daily milk yield per lactating cow of 71 pounds. Pregnancy rate was $19 \%$ and annual cull rate was $37 \%$.

The sensitivity analysis revealed that the optimum stocking density was very sensitive to reasonable changes in the size of the milk loss and prices.

Figure 1 displays the effects of milk losses of 1.1, 1.5, and 2 pounds/cow per day on gain in profitability for each 10 -percentage unit increase in number of cows per stall. The figure shows that the level of milk loss has a large effect on the optimal stocking density and the gain in profitability. At a loss of 1.1 pounds per cow per day, the maximum profit per milking stall is at a stocking density greater than $150 \%$. The profit per milking stall per year at $150 \%$ stocking density is $\$ 145$ greater than at a $100 \%$ stocking density. At a loss of 1.5 pounds/cow per day, the optimum stocking density is at $122 \%$, and the profit per milking stall per year is $\$ 43$ greater than at $100 \%$ stocking density. At a loss of 2 pounds/cow per stall, the optimum stocking density is at $107 \%$, and the profit per milking stall per year is only $\$ 6$ greater than at a $100 \%$ stocking density. Annual milk 
production per stall increased in all three cases to more than 33,069 pounds per year with stocking density at $150 \%$.

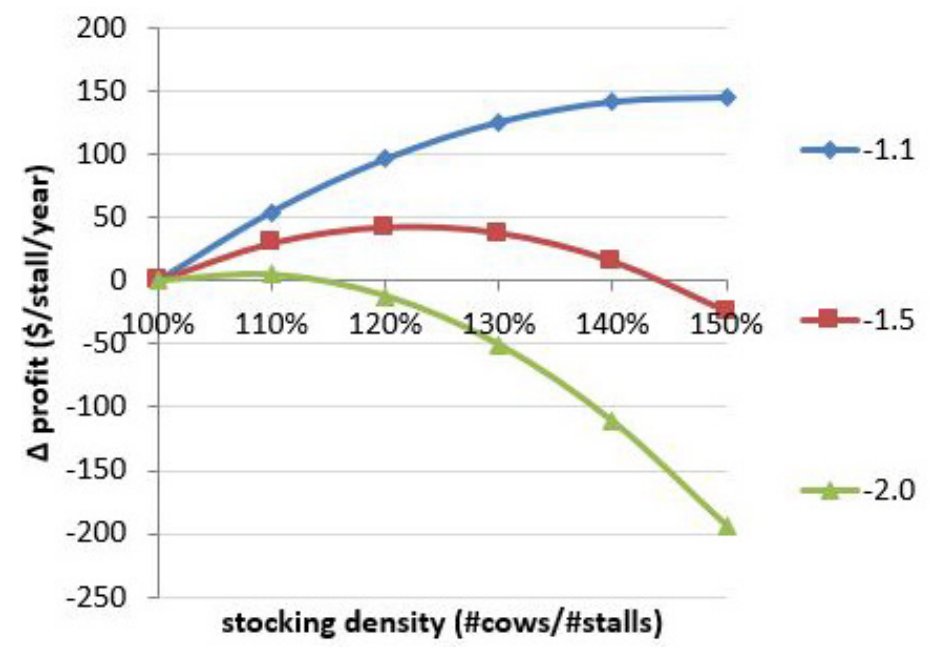

Figure 1. Profit per milking stall per year when stocking density is varied from 100 to $150 \%$ for three levels of milk loss $(-1.1,-1.5$, and -2 pounds per cow per day) per 10-percentage units increase in stocking density.

We varied milk prices from $\$ 0.18$ per pound to $\$ 0.22$ per pound ( $\$ 0.20$ was the default). We used a milk loss of $\$ 0.32$ per pound per cow per day. Higher milk prices increase the profitability of each additional cow and encourage a greater stocking density. With a milk price of $\$ 0.22$ per pound, the optimal stocking density was around $140 \%$ with a gain in profit of $\$ 180$ per stall per year compared to $100 \%$ stocking density. The lower milk price of $\$ 0.18$ per pound reduced the optimal stocking density to $100 \%$. At this milk price, overstocking was not profitable.

This scenario shows that less overstocking is economically better when milk prices are reduced or feed costs are increased. Farmers tend to overstock pens when milk income over feed cost is reduced, perhaps to maintain cash flow from milk sales. If more costs become variable instead of fixed, then the optimal stocking density will decrease.

Better reproduction through a higher 21-day service rate (estrus detection rate) increased the optimal stocking density, but it did not have as strong of an effect as changes in prices did. The optimal stocking density increased from $118 \%$ at a $34 \% 21$-day service rate to $128 \%$ at a $61 \% 21$-day service rate. Profitability increased by $\$ 25$ to $\$ 55$ per stall compared to $100 \%$ stocking density.

From the limited scenarios shown, it is clear that the economically optimal stocking density is very sensitive to reasonable ranges in prices that affect the revenues as well as costs that vary with the number of cows. On the other hand, the marginal value around the optimal stocking density is very low (a flat curve around the optimum; Figure 1), which means that profitability per stall is not reduced much when the optimal stocking density is reduced by 10 - or 20-percentage units.

\section{Spreadsheet}

The spreadsheet used to calculate these results is not userfriendly. Therefore, we captured the main associations in the spreadsheet in regression equations (De Vries, Dechassa, and Hogeveen 2016), which are called metamodels (models made from models). These metamodel regression equations were built into a separate spreadsheet so users could easily evaluate the effects from varying prices and stocking density on profitability and economically optimal stocking density. This spreadsheet is available at http:// dairy.ifas.ufl.edu/tools/index.shtml. Look for the Stall Stocking Density calculator.

\section{Conclusion}

Various studies concluded that an approximately $120 \%$ stocking density is the maximum allowable before cow behavior starts to be significantly affected. Many studies document the effects of short-term overstocking on cow behavior, but quantitative measures of overstocking on factors that affect cow cash flow (such as milk yield, fertility, and lameness) are scarce. Though economic analyses of stocking density are hampered by a lack of good performance data, we concluded that some overstocking is profitable under certain economic conditions in the US. There are also situations in which no overstocking or considerable overstocking is the most profitable. The economically optimal stocking density is quite sensitive to changes in milk and feed prices. Stocking density should be reduced when milk sales minus feed cost per cow decreases (low milk prices, high feed prices) to maximize profitability per stall. Welfare is hindered if overstocking exceeds approximately $20 \%$. There will be a trade-off between profitability and welfare in some situations.

\section{References}

Bach, A., N. Valls, A. Solans, and T. Torrent. 2008. "Associations between nondietary factors and dairy herd performance." Journal of Dairy Science 91: 3259-3267.

Bewley, J., R. W. Palmer, and D. B. Jackson-Smith. 2001. "Comparison of free-stall barns used by modernized Wisconsin dairies." Journal of Dairy Science 84: 528-541.

Cook, N. B. and K. Nordlund. 2002. "How environment affects cow longevity." In Proceedings of Midwest Dairy Herd 
Health Conference: November 12-13, 2002. 33-43. Madison, WI.

De Vries, A., H. Dechassa, and H. Hogeveen. 2016. "Economic evaluation of stall stocking density of lactating dairy cows." Journal of Dairy Science 99: 3848-3857.

Fregonesi, J. A., C. B. Tucker, and D. M. Weary. 2007. "Overstocking reduces lying time in dairy cows." Journal of Dairy Science 90: 3349-3354.

Grant, R. 2011. "Taking advantage of natural behavior improves dairy cow performance." eXtension. Accessed on December 7, 2017. http://www.extension.org/pages/11129/ taking-advantage-of-natural-behavior-improves-dairy-cowperformance

Krawczel, P. 2012. "Improving animal well-being through facilities management." Southern Dairy Conference, January 24, 2012. Accessed on December 7, 2017. http://www. southerndairyconference.com/Documents/2012Krawczel. pdf

Krawczel, P. and R. Grant. 2009. "Effects of cow comfort on milk quality, productivity, and behavior." eXtension. Accessed on July 26, 2018. http://articles.extension.org/ pages/70107/effects-of-cow-comfort-on-milk-qualityproductivity-and-behavior

Lima, F. S., A. De Vries, C. A. Risco, J. E. Santos, and W. W. Thatcher. 2010. "Economic comparison of natural service and timed artificial insemination breeding programs in dairy cattle." Journal of Dairy Science 93: 4404-4413.

Moore, D. A. 2010. “Stocking density: How much?” WesternDairyNews, December Vol. 10, No. 11.

Nordlund, K., N. Cook, and G. Oetzel. 2006. "Commingling dairy cows: Pen moves, stocking density, and health." In 39 Proceedings American Association Bovine Practitioners, September 20-24. 36-42. St. Paul, MN. Accessed on January 19, 2015. http://www.vetmed.wisc.edu/dms/fapm/fapmtools/tci/commingling.pdf

Schefers, J. M., K. A. Weigel, C. L. Rawson, N. R. Zwald, and N. B. Cook. 2010. "Management practices associated with conception rate and service rate of lactating Holstein cows in large, commercial dairy herds." Journal of Dairy Science 93: 1459-1467.
USDA APHIS. 2010. Dairy 2007: Facility Characteristics and Cow Comfort on U.S. Dairy Operations, 2007. Fort Collins, CO: USDA. Accessed on December 7, 2017. http:// www.aphis.usda.gov/animal_health/nahms/dairy/downloads/dairy07/Dairy07_ir_Facilities.pdf 